\title{
PENGARUH KEPEMIMPINAN DAN KOMUNIKASI TERHADAP KINERJA KARYAWAN PADA PT TELKOM WITEL MEDAN
}

\author{
May Handri ${ }^{1)}$ dan Junaidi Hasan ${ }^{2)}$ \\ Universitas IBBI \\ Email: handrimay76@gmail.com dan junaidihasan1961@gmail.com
}

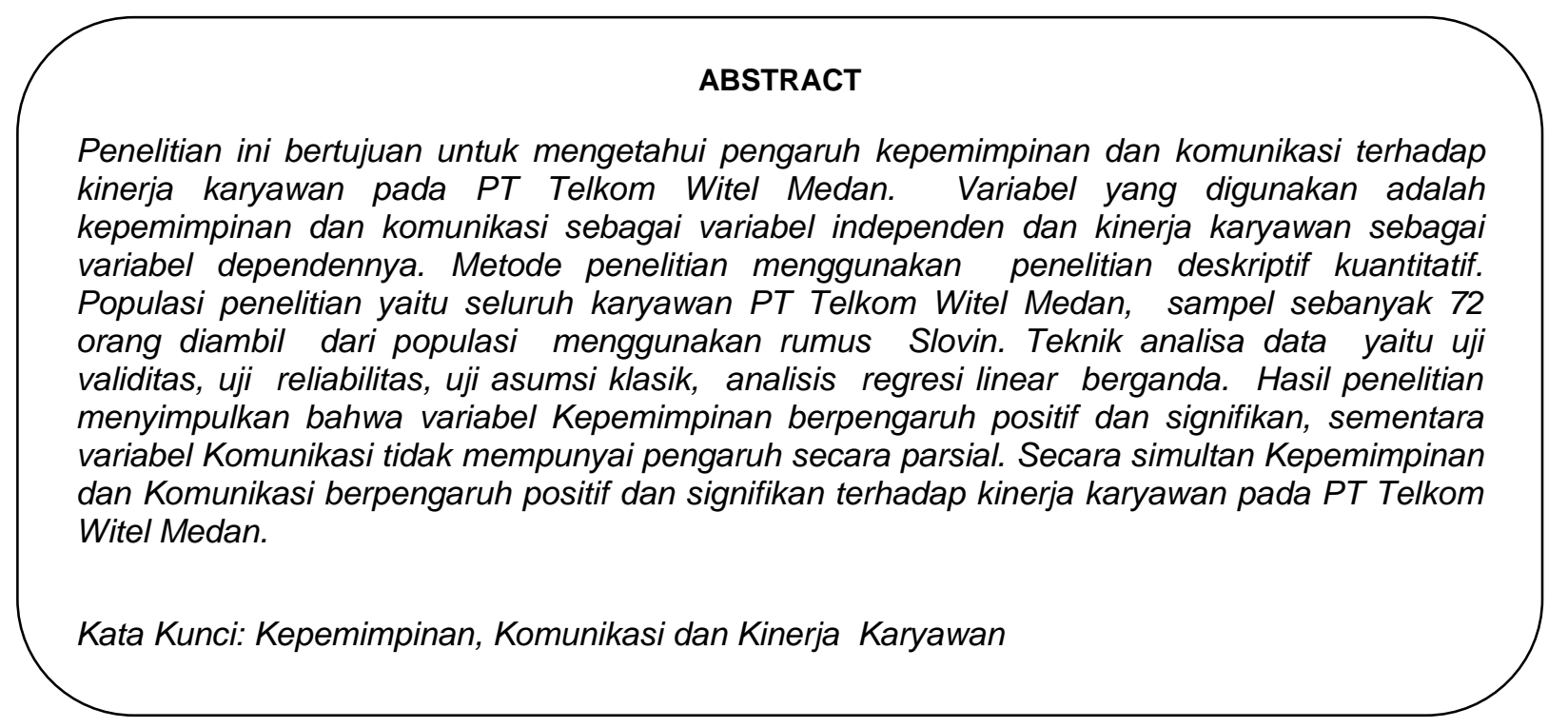

\section{Pendahuluan}

Pada zaman modernisasi saat ini, setiap perusahaan melakukan berbagai cara dalam menghadapi persaingan yang begitu ketat sehingga dapat bertahan. Perusahaan meningkatkan modal agar dapat bersaing dan berkembang sehingga dapat melawan perusahaan sejenis yang bergerak dibidang usaha yang sama. Salah satu yang perlu sangat diperhatikan oleh perusahaan adalah kualitas sumber daya manusia. Sumber daya manusia sangat penting perannya karena sumber daya manusia merupakan penggerak sumber daya lain seperti teknologi. Oleh karena itu, setiap perusahaan harus meningkatkan kinerja karyawannya agar dapat bersaing dengan kompetitor atau perusahaan lain. Kinerja karyawan yang baik akan meningkatkan laba perusahaan dan akan sangat mempengaruhi tujuan perusahaan yang ingin dicapai.

Kemampuan karyawan tercermin dari kinerja. Kinerja yang baik adalah kinerja yang optimal. Kinerja karyawan tersebut merupakan salah satu modal bagi perusahaan untuk mencapai tujuannya. Sehingga kinerja karyawan adalah hal yang patut diperhatikan oleh pemimpin perusahaan. Kinerja adalah hasil dari sebuah pekerjaan yang dihasilkan seorang karyawan di sebuah perusahaan dalam melaksanakan tugas yang telah diberikan oleh pemimpin atau atasannya. Karyawan dapat bekerja dengan baik bila memiliki kinerja yang tinggi, sehingga dapat menghasilkan kerja yang baik. Kinerja karyawan merupakan salah satu faktor penentu keberhasilan perusahaan atau organisasi dalam mencapai tujuannya. Untuk itu kinerja dari pada karyawan harus mendapat perhatian dari pimpinan perusahaan, sebab menurunnya kinerja dari karyawan dapat mempengaruhi kinerja perusahaan secara keseluruhan. Penurunan kinerja perusahaan bisa disebabkan oleh beberapa faktor, antara lain kepemimpinan dan komunikasi.

Kepemimpinan merupakan bagian yang sangat penting dalam kehidupan organisasi atau perusahaan. Kepemimpinan adalah kemampuan seseorang dalam mempengaruhi orang lain untuk melakukan tujuan yang disepakati bersama. Kepemimpinan yang efektif sangat dipengaruhi 
oleh kepribadian pimpinan. Setiap pemimpin perlu memiliki aspek-aspek kepribadian yang dapat menunjang usahanya dalam mewujudkan hubungan manusia yang efektif dengan anggota organisasinya. Kesuksesan atau kegagalan suatu organisasi ditentukan oleh banyak hal, yang salah satunya adalah kepemimpinan yang berjalan dalam organisasi tersebut. Pemimpin yang sukses adalah apabila pemimpin tersebut mampu menjadi pencipta dan pendorong bagi bawahannya dengan menciptakan suasana dan budaya kerja yang dapat memacu pertumbuhan dan perkembangan kinerja karyawannya.

Faktor kepemimpinan

yang

mempengaruhi kinerja antara lain kemampuan, kepribadian, pengalaman, intelektual dan lingkungan kerja, di mana faktor-faktor tersebut sangat berhubungan dengan keberhasilan pencapaian tujuan organisasi yaitu peningkatan kinerja, baik kinerja individu (karyawan) maupun organisasi. Dengan adanya dukungan kepemimpinan yang baik dan tepat pada suatu organisasi tentunya karyawan akan berupaya untuk mengembangkan kemampuan pribadi dan meningkatkan kemampuan di masa mendatang yang dipengaruhi oleh umpan balik mengenai kinerja kepemimpinan.

Komunikasi merupakan bagian penting dalam kehidupan kerja. Komunikasi adalah sebuah proses pertukaran fakta, ide-ide, opini atau emosi melalui kata-kata, simbol-simbol atau pesan. Komunikasi yang kurang lancar bisa berdampak luas terhadap kehidupan atau kelancaran organisasi misalnya masalah konflik antar karyawan maupun konflik atasan dan karyawan. Dan sebaliknya, komunikasi yang baik dapat menciptakan rasa saling menghargai dan memahami, meningkatkan kerja sama dan juga kepuasan kerja. Mengingat bekerja sama dalam sebuah organisasi untuk pencapain tujuan meliputi sumber daya manusia dengan berbagai macam karakter, maka komunikasi yang terbuka harus dikembangkan dengan baik. Dengan demikian, masing-masing karyawan dalam organisasi mengetahui tugas, tanggung jawab dan wewenang masingmasing. Dengan adanya komunikasi yang lancar di dalam perusahaan tentu akan lebih mempermudahkan karyawan dalam bekerja. Kesimpulannya komunikasi yang baik dapat meningkatkan kepuasan pekerjaan yang nantinya akan mengoptimalkan kinerja karyawan sehingga tujuan perusahaan dapat tercapai.

PT Telkom Witel Medan adalah perusahaan yang bergerak dibidang jasa pelayanan telekomunikasi dari jaringan di wilayah Indonesia dan karenanya tunduk pada hukum dan peraturan yang berlaku di Indonesia. Selain untuk telekomunikasi, perusahaan ini juga menyediakan jasa layanan Broad band Internet. Dan sekarang perusahaan ini mengembangkan pelayanannya menjadi Internet High Speed yang mana untuk membangun jaringan ini telah dibuat divisi khusus sebagai anak perusahaan dari PT Telkom Indonesia yaitu PT Telkom Akses. Divisi ini didirikan untuk mempermudah pengembangan jaringan yang awalnya hanya menggunakan kabel yang terbuat dari tembaga dan sekarang menggunakan kabel listrik serat optik yang menyimpan kecepatan tinggi.

Berdasarkan pengamatan yang dilakukan pada PT Telkom Witel Medan bahwa terjadi penurunan kinerja karyawan yang dapat dilihat dari jumlah pelanggan yang menggunakan layanan jaringan IndiHome di kota Medan. Penurunan jumlah pelanggan terjadi karena terdapat masalah kinerja karyawan pada perusahaan ini yaitu pada masalah kualitas pekerjaan, dimana dapat dilihat dari karyawan perusahaan yang mulai tidak sesuai melakukan pekerjaan mereka seperti kurang tanggapnya karyawan dalam memberikan layanan kepada pelanggan. Terkadang karyawan PT Telkom tidak tepat waktu dalam menangani keluhan pelanggan seperti seiring maraknya iklan yang dipasang pihak perusahaan tentang layanan Indihome yang dapat menjangkau kecepatan tinggi (High Speed) dengan menggunakan modem Fiber Optik (Fo) ternyata tidak sesuai yang terjadi di lapangan, pelanggan menunggu lama sampaisampai harus menghubungi pihak PT Telkom untuk beberapa kali dan ada juga beberapa pelanggan yang langsung datang ke perusahaan untuk komplain mengenai gangguan jaringan yang mereka alami, maka barulah ada tindak lanjut dari karyawan PT Telkom.

Masalah lain yang terlihat yaitu terdapat beberapa karyawan yang memiliki kesadaran yang rendah akan disiplin dan tanggung jawab dalam menjalankan tugas yang sudah diberikan oleh pimpinan. Seperti, masih terdapat beberapa karyawan yang terlambat masuk kerja dan kurangnya tingkat kehadiran pada upacara pagi. Keadaan seperti ini dapat berakibat pada menurunnya kinerja karyawan. Hal ini dapat disebabkan oleh adanya masalah yang terjadi pada kepemimpinan dan komunikasi di perusahaan tersebut.

Selain itu, masih ada hambatan dalam penyampaian suatu informasi dari karyawan kepada pimpinan. Hambatannya adalah berupa banyaknya saluran yang harus dilalui untuk dapat menyampaikan informasi. Apabila 
semakin lama permasalahan tersebut tidak ditindaklanjuti maka kerja sama untuk mencapai tujuan di dalam perusahaan tersebut akan sulit tercapai dengan maksimal sesuai dengan target perusahaan.

\section{Literatur Review Kepemimpinan}

Kepemimpinan merupakan salah satu faktor yang sangat penting dalam mempengaruhi prestasi organisasi, karena kepemimpinan merupakan aktivitas utama agar tujuan organisasi dapat dicapai. Menurut Thoha (2013) menyatakan bahwa kepemimpinan adalah kegiatan untuk perilaku orang lain, atau seni mempengaruhi perilaku orang lain, atau seni mempengaruhi perilaku manusia baik perorangan maupun kelompok.

Chung dan Megginson menyatakan bahwa kepemimpinan adalah sebagai kesanggupan untuk mempengaruhi perilaku orang lain dalam suatu arah tertentu (Bangun, 2012). Menurut Greenberg dan Baron dalam (Wibowo, 2013) memberikan definisi kepemimpinan sebagai proses dimana satu invidu mempengaruhi anggota kelompok lain menuju pencapaian tujuan kelompok atau organisasional yang didefenisikan

Berdasarkan definisi diatas, dapat disimpulkan bahwa kepemimpinan pada hakikatnya adalah kemampuan individu dalam menggunakan kekuasaannya melalui proses mempengaruhi dan mendukung usaha orang lain yang memungkinkan orang tersebut memberikan kontribusi kepada pencapaian tujuan organisasi

\section{Komunikasi}

Berkomunikasi merupakan salah satu diantara fungsi pokok manajemen. Setiap orang berkomunikasi dalam suatu organisasi. Istilah berkomunikasi atau communication berasal dari bahasa Latin, yaitu communication yang berarti pemberitahuan atau pertukaran. Kata sifatnya, communis yang bermakna umum atau bersama-sama. Komunikasi yang kurang baik dapat mengganggu kelancaran organisasi yang berkomunikasi dalam usaha mencapai sasarannya.

Thoha dalam Arifin, (2012) mengungkapkan komunikasi adalah suatu proses penyampaian dan penerimaan berita atau informasi dari seseorang ke orang lain. Sedangkan Kreitner dan Kinicki dalam Wibowo, (2013), mengatakan bahwa komunikasi adalah "pertukaran informasi antara sender dan receiver, dan menarik kesimpulan sebagai persepsi tentang maksa sesuatu antara individual yang terlibat.
Dari beberapa pendapat ahli di atas dapat disimpulkan bahwa komunikasi adalah penyampaian suatu informasi dari seseorang kepada orang lain yang sangat harus diperhatikan sehingga tercapai tujuan yang dimaksud. Komunikasi merupakan cara bagi anggota organisasi untuk saling memahami dan saling mengerti. Maka dari itu komunikasi menjadi sesuatu yang sangat penting karena komunikasi dapat meningkatkan rasa saling pengertian antar karyawan dan atasan, meningkatkan koordinasi dari berbagai macam kegiatan atau tugas yang berbeda, dan meningkatkan kepuasan kerja.

\section{Kinerja}

Menurut Sedarmayanti (2015) bahwa kinerja adalah catatan mengenai outcome yang dihasilkan dari suatu aktivitas tertentu, selama kurun waktu tertentu pula. Sedangkan menurut Rivai dan Basri dalam Kaswan (2012) kinerja adalah hasil atau tingkat keberhasilan seseorang secara keseluruhan selama satu periode tertentu di dalam melaksanakan tugas dibandingkan dengan berbagai kemungkinan, seperti standar hasil kerja, target atau sasaran atau kriteria yang telah ditentukan terlebih dahulu dan telah disepakati bersama".

Wilson (2012), kinerja (performance) adalah hasil pekerjaan yang dicapai seseorang berdasarkan persyaratan-persyaratan pekerjaan. Suatu pekerjaan mempunyai persyaratan tertentu untuk dapat digunakan dalam mencapai tujuan yang disebut juga sebagai standar pekerjaan. Sementara menurut Sunyoto (2013), menyatakan bahwa "kinerja adalah suatu hasil yang dicapai seseorang dalam melaksanakan dan menyelesaikan pekerjaaan yang dibebankan kepadanya. Siswanto dalam Sandy, (2015) memberikan pengertian bahwa kinerja ialah prestasi yang dicapai oleh seseorang dalam melaksanakan tugas dan pekerjaan yang diberikan kepadanya.

Dari berbagai defenisi kinerja menurut para ahli di atas, maka dapat disimpulkan bahwa kinerja adalah hasil kerja, baik secara kualitas maupun kuantitas, yang dicapai oleh sumber daya manusia sesuai dengan peran dan tanggung jawab yang dibebankan kepadanya dalam rangka pencapaian tujuan organisas

\section{Metodelogi}

Penelitian ini menggunakan metode kuantitatif. Populasi penelitian yang akan digunakan dalam penelitian adalah karyawan 
PT. Telkom Wilayah Medan sebanyak 72 orang karyawan.

\section{Hasil dan Pembahasan Uji Validitas}

"Pengujian signifikansi dilakukan dengan kriteria menggunakan rtabel pada tingkat signifikansi 0,05 dengan uji 2 sisi. Jika nilai positif dan $r_{\text {hitung }}>r_{\text {tabel }}$, item dapat dinyatakan valid dan sebaliknya Jika nilair hitung $<r_{\text {tabel}}$, item dinyatakan tidak valid.

\section{Uji Realibilitas}

Secara umum pengambilan keputusan untuk uji reliabilitas dapat menggunakan kategori sebagai berikut :

1. Cronbach's alpha $<0,6=$ reliabilitas buruk.

2. Cronbach's alpha $0,6-0,79=$ reliabilitas diterima.

3. Cronbach's alpha $0,8=$ reliabilitas baik

\section{Uji Normalitas}

Uji normalitas residual digunakan untuk menguji apakah nilai residual yang dihasilkan dari regresi terdistribusi secara normal atau tidak. Model regresi yang baik adalah memiliki residual yang terdistribusi secara normal. Beberapa metode uji normalitas yaitu dengan melihat penyebaran data pada sumber diagonal pada grafik Normal Probability Plot of Regression atau dengan uji One Sample Kolmogorov Smirnov. Berikut ini pembahasannya.

\section{Uji Multikolinieritas}

Multikolinieritas adalah keadaan pada model regresi ditemukan adanya korelasi yang sempurna atau mendekati sempurna antarvariabel independen dimana model regresi yang baik seharusnya tidak terjadi korelasi sempurna atau medekati sempurna diantara variabel bebas. Priyatno (2018), "Metode uji multikolinieritas yang umum digunakan yaitu dengan melihat nilai Tolerance dan Variance Inflation Factor (VIF) pada model regresi dimana nilai VIF kurang dari 10 dan mempunyai angka Tolerance lebih dari 0,1

\section{Uji Heteroskedastisitas}

Priyatno (2018) heteroskedastisitas adalah keadaan dimana dalam model regresi terjadi ketidaksamaan varian dari residual pada satu pengamatan ke pengamatan lainnya dimana model yang regresi yang baik adalah tidak terjadi heteroskedastisitas.. Untuk pengujian kedua adalah pengujian Glejser mengusulkan untuk meregres nilai absolut residual terhadap variabel independen apabila probabilitas signifikansinya di atas tingkat

\section{Analisis Regresi Linier Berganda}

Menurut Sunyoto (2014) analisis regresi berganda untuk mengetahui pengaruh dua atau lebih variabel bebas $\left(X_{1,2,3, \ldots n}\right)$ terhadap variabel terikat $(Y)$ ". Tujuan digunakan analisis regresi berganda pada penelitian ini adalahuntuk mengetahui seberapa besar pengaruh kompensasi, budaya organisasi, gaya kepemimpinan dan disiplin kerja terhadap kepuasan kerja karyawan pada Restoran Sari Laut Nelayan:

$$
Y=a+b_{1} X_{1}+b_{2} X_{2}+e
$$

Keterangan :

$\mathrm{Y}=$ Kinerja

$\mathrm{a}=$ Konstanta

$\mathrm{b}_{1}=$ Koefisien regresi Pertama

$\mathrm{X}_{1}=$ Kepemimpinan

$\mathrm{b}_{2}=$ Koefisien regresi Kedua

$\mathrm{X}_{2}=$ Komunikasi

$\mathrm{e}=$ Standard Error

\section{Uji Validitas}

Seluruh $r_{\text {hitung }}$ tiap pernyataan memiliki nilai lebih besar dari $r_{\text {tabel }}$ dan seluruh tingkat signifikan pada pernyataanlebih besar dari 0,05 sehingga diperoleh hasil bahwa semua pernyataan dalam kuesioner adalah valid karena semua nilai thitung $>$ nilai $t$ kritis yaitu 0,30 .. Dengan demikian maka kuesioner dapat digunakan untuk melakukan pengecekan terhadap kehandalan kuesioner tersebut atau dilakukan pengujian reliabilitas.

\section{Uji Reliabilitas}

Cara pengukuran reliabilitas adalah seluruh item pernyataan yang telah valid dimasukan dan diukur koefisien Cronbach's Alpha.

\section{Tabel 1. Uii Reliabilitas Instrumen}

\begin{tabular}{|cl|c|c|}
\hline \multicolumn{2}{|l|}{ Variabel } & $\begin{array}{c}\text { Cronbach's } \\
\text { Alpha }\end{array}$ & N of Items \\
\hline 1. & Kepemimpinan $\left(\mathrm{X}_{1}\right)$ & 0,881 & 5 \\
\hline 2. & Komunikasi $\left(\mathrm{X}_{2}\right)$ & 0,724 & 5 \\
\hline 3. & Kinerja $(\mathrm{Y})$ & 0,706 & 6 \\
\hline
\end{tabular}

Setiap alat pengukur seharusnya memiliki kemampuan untuk memberikan hasil pengukuran relatif konsisten dari waktu ke waktu. Metode yang digunakan untuk melihat data sudah realibel dengan metode Cronbach's Alpha ( $\alpha$ ). Koefisien Cronbach's Alpha ( $\alpha$ ) yang digunakan dalam penelitian ini adalah $\alpha>0,60$, 
sehingga jawaban yang diberikan responden dapat dipercaya atau dapat diandalkan.

\section{Uji Normalitas}

Data menyebar disekitar garis diagonal dan mengikuti arah garis diagonal atau grafik histogramnya menunjukkan pola distribusi normal dengan tidak melenceng ke kiri maupun ke kanan dan berbentuklonceng, maka regresi dianggap memenuhi asumsi normalitas. Pada gambar normal probability plot diatas dapat dilihat bahwa titik-titik mendekati garis diagonal. Hal ini menunjukkan bahwa data berdistribusi normal dan memenuhi asumsi pengujian normalitas. Pada tabel diatas, dapat dilihat bahwa hasil pengujian normalitas Kolmogorovsmirnov membuktikan bahwa variabel penelitian berdistribusi normal karena nilai Asympy.Sig (2tailed) $\mathrm{X}_{1}$ (kepemimpinan) sebesar 0,416, $\mathrm{X}_{2}$ (komunikasi) sebesar 0,149 dan $Y$ (kinerja) sebesar 0,720 . Karena signifikansi pada ketiga variabel lebih dari 0,05 jadi dapat dinyatakan data berdistribusi normal.

\section{Uji Multikolinieritas}

Nilai korelasi untuk variabel kompensasi, budaya organisasi, gaya kepemimpinan dan disiplin kerja mempunyai nilai tolerance yang lebih besar dari 0,10 dan nilai VIF yang lebih kecil dari 10 . Tolerence-nya $>0,1$ dan nilai VIF < 10 maka tidak ditemukan masalah multikolinearitas dalam penelitian ini, sehingga dapat disimpulkan bahwa seluruh variabel tidak terdapat adanya gejala multikolinieritas.

\section{Uji Heteroskedastisitas}

Berdasarkan pada tabel di atas, maka dapat dilihat bahwa variabel kompensasi, budaya organisasi, gaya kepemimpinan dan disiplin kerja memiliki nilai tingkat signifikansi yang lebih besar dari 0,05 sehingga dari hasil perhitungan dan tingkat signifikan diatas maka tidak ditemukan adanya terjadi heteroskedastisitas. titik-titik menyebar secara acak dan tidak membentuk suatu pola tertentu yang jelas tersebar baik diatas maupun dibawah angka nol pada sumbu Y. Hal ini tidak terjadi heterokedastisitas pada model regresi, sehingga model regresi layak dipakai untuk memprediksi kinerja berdasarkan variabel independen.

\section{Analisis Regresi Linier Berganda}

Analisis regresi berganda digunakan untuk mengetahui seberapa besar pengaruh variabel bebas yaitu kepemimpinan dan komunikasi terhadap variabel terikat yaitu kinerja.

\section{Tabel 2. Hasil Analisis Regresi Linier Berganda}

\begin{tabular}{|c|c|c|c|c|c|}
\hline \multirow[t]{2}{*}{ Model } & \multicolumn{2}{|c|}{$\begin{array}{l}\text { Unstandardized } \\
\text { Coefficients }\end{array}$} & \multirow{2}{*}{$\begin{array}{c}\begin{array}{c}\text { Standardiz } \\
\text { ed } \\
\text { Coefficients }\end{array} \\
\text { Beta }\end{array}$} & \multirow[b]{2}{*}{$t$} & \multirow[b]{2}{*}{ Sig. } \\
\hline & $B$ & $\begin{array}{l}\text { Std. } \\
\text { Error }\end{array}$ & & & \\
\hline $1 a$ & 16.000 & 2.911 & & 5.497 & .000 \\
\hline $\mathrm{X} 1$ & .640 & .075 & .696 & 8.520 & .000 \\
\hline $\mathrm{X} 2$ & -.253 & .117 & -.177 & -2.170 & .033 \\
\hline
\end{tabular}

a. Dependent Variable: $Y$

Persamaan regresi linier berganda yaitu dengan rumus berikut :

$$
Y=16.000+0,640 X_{1}-0,253 X_{2}
$$

Berdasarkan persamaan tersebut dapat digambarkan bahwa konstanta $=16.000$, artinya jika variabel kinerja pada PT Telkom Witel Medan tidak dipengaruhi oleh faktor kepemimpinan dan komunikasi maka kinerja pada perusahaan di atas sebesar 16.000 satuan. Nilai kepemimpinan $\left(X_{1}\right)=0,640$, artinya setiap penambahan satu-satuan faktor kepemimpinan mengakibatkan bertambahnya kinerja pada PT Telkom Witel Medan sebesar 0,640 satu-satuan dengan kondisi faktor komunikasi dianggap nol. Nilai komunikasi $\left(\mathrm{X}_{2}\right)$ $=-0,253$, artinya setiap penambahan satusatuan faktor komunikasi mengakibatkan menurunnya kinerja pada PT Telkom Witel Medan sebesar -0,253 satu-satuan dengan kondisi faktor kepemimpinan dianggap nol

\section{Kesimpulan}

1. Variabel kepemimpinan $\left(X_{1}\right)$ berpengaruh secara positif dan signifikan terhadap kinerja karyawan pada PT Telkom Witel Medan (Y).

2. Bariabel komunikasi $\left(X_{2}\right)$ berpengaruh secara negatif terhadap kinerja karyawan pada PT Telkom Witel Medan (Y).

3. Variabel komunikasi.Variabel kepemimpinan $\left(X_{1}\right)$ dan komunikasi $\left(X_{2}\right)$ berpengaruh secara positif dan signifikan terhadap kinerja karyawan pada PT Telkom Witel Medan (Y). 


\section{DAFTAR PUSTAKA}

